\title{
STRUKTUR MODAL DAN PROFITABILITAS TERHADAP NILAI PERUSAHAAN
}

\author{
Risma Nopianti \\ rismanopianti92@gmail.com \\ Suparno \\ suparno.padikromo@fe.unsika.ac.id \\ Universitasi Singaperbangsa Karawang
}

\begin{abstract}
This study aims to examine the effect of capital structure and profitability on firm value both partially and simultaneously. The capital structure variable is proxied by Debt Equity Ratio (DER), the Profitability Variable is proxied by Return On Equity (ROE) and Company Value is proxied by Price To Book Value (PBV). This type of research uses explanatory research with a quantitative approach, the population in the study are all food and beverage sub-sector manufacturing companies listed on the Indonesia Stock Exchange in the period 2014-2018. With a purposive sampling technique with a sample size of 10 companies. The data obtained were analyzed by testing the validity of the data, multiple linear regression analysis, and hypothesis testing using the $t$ test and $f$ test. The results of this study indicate that capital structure has a positive and significant effect on firm value, profitability has a positive and significant effect on firm value, and capital structure and profitability together have a positive and significant effect on firm value.
\end{abstract}

Keywords: capital structure, profitability, and firm value

\begin{abstract}
Abstrak
Penelitian ini bertujuan untuk menguji pengaruh struktur modal dan profitabilitas terhadap nilai perusahaan baik secara partial maupun secara simultan. Variabel Struktur modal diproksikan Debt Equity Ratio (DER), Variabel Profitabilitas diproksikan oleh Return On Equity (ROE) dan Nilai Perusahaan diproksikan oleh Price To Book Value ( PBV ). Jenis penelitian ini menggunakan metode deskriptif verifikatif dengan pendekatan kuantitatif, Populasi dalam penelitian adalah seluruh perusahaan manufaktur sub sektor makanan dan minuman yang terdaftar di Bursa Efek Indonesia tahun 2014 -2018. Dengan teknik purposive sampling dengan jumlah sampel sebanyak 10 perusahaan. Data yang diperoleh dianalisis dengan pengujian keabsahaan data, analisis regresi linier berganda, dan uji hipotesis menggunakan uji t dan uji f. Hasil penelitian ini menunjukan bahwa struktur modal berpengaruh positif dan signifikan terhadap nilai perusahaan, profitabilitas berpengaruh positif dan signifikan terhadap nilai perusahaan, dan struktur modal dan profitabilitas secara bersama-sama berpengaruh secara positif dan signifikan terhadap nilai perusahaan.
\end{abstract}

Kata kunci: struktur modal, profitabilitas, dan nilai perusahaan 


\section{PENDAHULUAN}

Perekonomian dunia saat ini secara tidak langsung berimbas kepada perekonomian Indonesia. Persaingan dalam dunia industri pun berjalan begitu pesat yang dapat menciptakan persaingan yang sangat ketat khususnya dalam persaingan yang terjadi di perusahaan manufaktur sub sektor makanan dan minuman yang menjadi salah satu sub sektor andalan bagi kelangsungan hidup manusia. Dalam pertumbuhan ekonomi yang terjadi pada tahun 20142018, sub sektor makanan dan minuman mampu tumbuh sebesar 5,17\% yang salah satunya disebabkan oleh meningkatnya produksi industri makanan dan minuman. Akan tetapi berbeda dalam pertumbuhan ekonomi tahun 2019 malah mengalami pelambatan yang dilihat dari industri makanan dan minuman yang hanya tumbuh 5,02 persen. Pada fenomena yang terjadi diatas bisa berdampak pada harga pasar saham suatu perusahaan khususnya perusahaan makanan dan minuman. Harga saham dapat menunjukan penilaian yang sentral dari seluruh pelaku pasar, harga saham pun bertindak sebagai barometer kinerja manajaemen suatu perusahaan. Harga saham yang tinggi akan membuat nilai suatu perusahaan juga tinggi (Rudangga,2016). Nilai perusahaan sangat penting sebab dengan nilai perusahaan yang tinggi akan diikuti oleh tingginya kemakmuran para pemegang saham (Brigham and Gapensi, 1996; Syarinah, 2017). Akan tetapi pertumbuhan rata-rata nilai perusahaan pada seluruh perusahaan sub sektor makanan dan minuman yang terdaftar di Bursa Efek Indonesia selama tahun 20142018 tidak maksimal. Pertumbuhan rata-rata nilai perusahaan dapat dilihat pada tabel 1 .

Tabel 1

\begin{tabular}{lrrrrr}
\multicolumn{5}{c}{ Rata-rata } & Price to Book Value (PBV) \\
\hline Tahun & 2014 & 2015 & 2016 & 2017 & 2018 \\
\hline PBV & 8,379 & 5,423 & 6,158 & 5,633 & 5,749 \\
\hline Pertumbuhan & & $-2,956$ & 0,735 & $-0,525$ & 0,116 \\
\hline
\end{tabular}

Sumber: data diolah, 2020

Masalah nilai perusahan pada tabel 1 yang diproxsikan oleh Price to Book Value (PBV), dan Nilai perusahaan dapat dipengaruhi oleh beberapa faktor berikut ini: keputusan pendanaan, kebijakan deviden, keputusan investasi, struktur modal, laverage, profitabilitas, pertumbuhan perusahaan, dan ukuran perusahaan (Rudangga, 2016). Dari beberapa faktor di atas yang mempengaruhi nilai perusahaan, peneliti membatasi hanya meneliti dua faktor yaitu struktur modal dan profitabilitas. Semakin tinggi nilai rasio DER maka semakin tinggi pendanaan yang diberikan kreditur terhadap perusahaan melalui hutang, maka semakin sulit perusahaan mendapatkan pendanaan karena dikhawatirkan tidak mampu untuk menutupi hutang-hutang tersebut. Maka nilai perusahaan akan turun jika nilai rasio DER tinggi (Syarinah, 2017). Sedangkan nilai dari suatu perusahaan dipengaruhi dari besar kecilnya profitabilitas yang dihasilkan oleh perusahaan tersebut, karena semakin besar profitabilitas akan membuat nilai perusahaan semakin tinggi dan membuat investor semakin berani menginvestasikan di perusahaan tersebut (Rudangga, 2016). Berdasarkan uraian diatas mengenai faktor yang mempengaruhi nilai perusahaan yang terdiri dari struktur modal dan profitabilitas, maka peneliti tertarik untuk melakukan penelitian mengenai faktor tersebut. 


\section{TINJAUAN PUSTAKA}

Teori keagenan mejelaskan suatu keterkaitan antara agent dan principal. Agent merupakan manajemen perusahaan sedangkan yang dimaksud principal adalah pemilik (pemegang saham). Teori keagenan adalah adanya pemisahaan hak milik perusahaan dan pertanggungjawaban atas pembuatan keputusan (Jensen and Mackling, 1976; Ratih \& Ayu, 2016). Teori sinyal merupakan suatu tindakan yang diambil oleh manajemen perusahaan untuk memberikan petunjuk kepada para investor tentang bagaimana manajemen memandang prospek perusahaan (Brigham dan Houston, 2011:184; Sadewo,et.al, 2016). Teori sinyal menjelaskan mengapa suatu perusahaan mempunyai dorongan untuk memberikan informasi laporan keuangan pada pihak-pihak eksternal. Nilai Perusahaan, menurut Rita dan Irham (2018) mendefiniskan nilai perusahaan merupakan penilaian atau persepsi investor sebagai calon pembeli untuk tingkat keberhasilan suatu perusahaan dan kinerja perusahaan yang tercemin melalui harga saham dipasar. Struktur Modal, menurut Fahmi (2014: 78), merupakan gambaran dan bentuk proforsi financial perusahaan yaitu antara modal dimiliki yang bersumber dari hutang jangka panjang dan modal sendiri.,. Profitabilitas, menurut Dewi (2016) mendefinisikan rasio profitabilitas sebagai kemampuan perushaan dalam menghasilkan keuntungan dalam usahanya. Semakin tinggi tingkat keuntungan menunjukan semakin baik manajemen dalam mengelola perusahaan.

\section{PENGEMBANGAN HIPOTESIS}

Pengaruh struktur modal terhadap nilai perusahaan, menurut Syarinah (2017), semakin tinggi nilai rasio DER maka semakin tinggi pendanaan yang diberikan kreditur terhadap perusahaan melalui hutang, maka semakin sulit perusahaan mendapatkan pendanaan karena dikhawatirkan tidak mampu untuk menutupi hutang-hutang tersebut. Maka nilai perusahaan akan turun jika nilai rasio DER tinggi. Teori ini sejalan dengan hasil penelitian yang dilakukan oleh Sulastri, et al. (2018) menunjukan bahwa struktur modal berpengaruh negatif terhadap nilai perusahaan. Adapun hipotesis dalam penelitian ini adalah sebagai berikut:

H1: Struktur modal (DER) berpengaruh terhadap nilai perusahaan

Pengaruh Profitabilitas terhadap Nilai Perusahaan, menurut Rudangga (2016), nilai dari suatu perusahaan dipengaruhi dari besar kecilnya profitabilitas yang dihasilkan oleh perusahaan tersebut, karena semakin besar profitabilitas akan membuat nilai perusahaan semakin tinggi dan membuat investor semakin berani menginvestasikan di perusahaan tersebut. Teori ini sejalan dengan hasil penelitian yang dilakukan oleh Mamay dan Naufal (2019), menunjukan bahwa terdapat pengaruh positif antara profitabilitas dengan Nilai Perusahaan. Adapun hipotesis dalam penelitian ini adalah sebagai berikut:

$\mathrm{H} 2$ : Profitabilitas (ROE) berpengaruh terhadap nilai perusahaan 
Pengaruh Struktur Modal dan Profitabilitas terhadap Nilai Perusahaan, hal-hal yang dapat mempengaruhi nilai perusahaan adalah sebagai berikut: keputusan pendanaan, kebijakan deviden, keputusan investasi, struktur modal, laverage, profitabilitas, pertumbuhan perusahaan, dan ukuran perusahaan (Rudangga, 2016). Teori ini diperkuat oleh penelitian yang dilakukan Heven dan Fitty (2016) dengan hasil bahwa struktur modal dan profitabilitas berpengaruh terhadap nilai perusahaan.

H3: Struktur modal (DER) dan profitabilitas (ROE) berpengaruh terhadap nilai perusahaan

\section{METODE PENELITIAN}

Metode yang digunakan dalam penelitian ini yaitu metode deskriptif verifikatif dengan pendekatan kuantitatif. Data penelitian ini merupakan data sekunder yang diperoleh dari laporan keuangan tahunan dan harga saham perusahaan manufaktur sub sektor makanan dan minuman yang terdaftar di Bursa Efek Indonesia. Teknik sampling yang digunakan adalah teknik purposive sampling dengan kriteria yang telah ditetapkan oleh peneliti yang dapat menjadi pertimbangan. Sehingga dari total populasi sebanyak 26 perusahaan diperoleh sebanyak 10 perusahaan yang digunakan sebagai sampel pada tahun 2014-2018. Adapun teknik analisis data yang digunakan terdiri dari uji asumsi klasik, analisis regresi linier berganda, uji hipotesis, dan uji koefisien determinasi. Definisi Operasional, menurut Sugiyono (2016:38), definisi operasional suatu atribut atau sifat atau nilai dari objek peneliti untuk dipelajari dan kemudian ditarik kesimpulannya. Dibawah ini adalah definisi operasional dari struktur modal, profitabilitas, dan nilai perusahaan: Struktur Modal (X1), besarnya total kewajiban yang dimiliki oleh suatu perusahaan dengan modal sendiri yang dimiliki oleh perusahaan.

$$
\begin{gathered}
\text { DER }=\frac{\text { Total utang }}{\text { Total Equity }} \boldsymbol{x} \mathbf{1 0 0} \% \text {.............................1) } \\
\text { Sumber: Pratama dan Wirawati (2016) }
\end{gathered}
$$

Profitabilitas (X2), besarnya laba bersih yang dihasilkan terhadap total modal yang dimiliki oleh perusahaan.

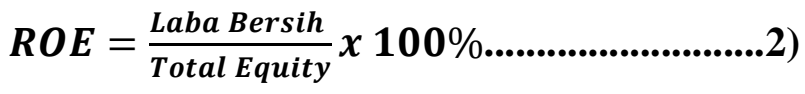

$$
\begin{aligned}
& \text { Sumber: Kasmir (2014) }
\end{aligned}
$$

Nilai Perusahaan (Y), besarnya harga pasar perlembar saham yang dimiliki perusahaan terhadap nilai buku perlembar saham yang dimiliki perusahaan dan juga besarnya jumlah modal yang dimiliki terhadap jumlah saham yang beredar dalam perusahaan

$$
P B V=\frac{\text { Harga Pasar Perlembar Saham }}{\text { Nilai Buku Perlembar Saham }}
$$

Keterangan:

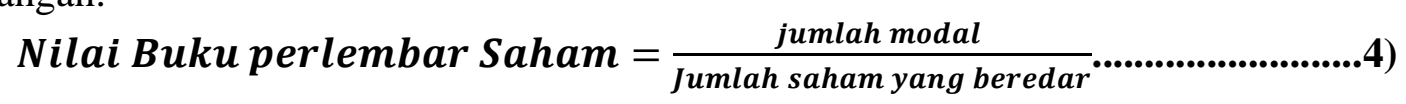

Sumber: Pratama dan Wirawati (2016) 


\section{HASIL DAN PEMBAHASAN}

Analisis Statistik Deskriptif, analisis statistik deskriptif bertujuan untuk menganalisis sebuah data dengan cara mendeskripsikan atau menggambarkan data yang telah terkumpul secara statistik. Analisis statistik deskiptif dalam penelitian ini meliputi nilai mean, minimum, maximum, dan standar deviasi pada setiap variabelnya. Berikut ini adalah data yang telah diolah sehingga menghasilkan analisis deskriptif:

\section{Tabel 2}

Hasil Analisis Statistik Deskriptif

\begin{tabular}{llllll}
\hline \multicolumn{5}{c}{ Descriptive Statistics } \\
\hline Nilai Perusahaan & 50 & Minimum & Maximum & Mean & Std. Deviation \\
Struktur Modal & 50 & 16.354 & 35.465 & 6.268 & 8.832 \\
Profitabilitas & 50 & 4.360 & 143.533 & 88.787 & 55.043 \\
Valid N (listwise) & 50 & & 25.933 & 30.672 \\
\hline \multicolumn{7}{c}{ Sur } & & \\
\hline
\end{tabular}

Sumber: Data diolah (2020)

Berdasarkan hasil pengujian diatas dengan jumlah N 50 dapat diketahui bahwa variabel nilai perusahaan memiliki nilai minimum 0,628 , maximum 45,465, mean 6,268 , dan standar deviasinya 8,832. Variabel struktur modal memiliki nilai minimum 16,354, maximum 302,864 , mean 88,787 , dan standar deviasinya 55,043. Variabel profitabilitas memiliki niali minimum 4,360, maximum 143,533, mean 25,933, dan standar deviasinya 30,672.

Uji Asumsi Klasik, Uji Normalitas, Uji normalitas bertujuan untuk menguji apakah dalam sebuah model regresi linier variabel terikat dengan variabel bebas kedua-duanya mempunyai distribusi yang normal atau tidak. Berikut adalah hasil dari uji normalitas:

Tabel 3

Hasil Uji Normalitas

\begin{tabular}{llr}
\hline \multicolumn{2}{c}{ One-Sample Kolmogorov-Smirnov Test } \\
\hline $\mathrm{N}$ & $\begin{array}{r}\text { Unstandardized } \\
\text { Residual }\end{array}$ \\
Normal Parameters ${ }^{\mathrm{ab}}$ & Mean & 50 \\
& Std. Deviation & 0.000 \\
Most Extreme Difference & Absolute & 2.008 \\
& Positive & 0.082 \\
& Negative & 0.080 \\
Kolmogorov-Smirnov Z & & -0.082 \\
Asymp. Sig. (2-tailed) & & 0.582 \\
a.Test distribution is Normal & & 0.887 \\
b.Calculated data & \\
\hline
\end{tabular}

Sumber: Data diolah (2020)

Hasil pengujian diperoleh nilai Asymp.sig. (2-tailed) sebesar 0,887. Karena nilai 0,887 > dari 0,05 , maka dapat disimpulakan bahwa data berdistribusi normal.

Uji Mulikolinieritas, uji multikolinieritas untuk menguji apakah sebuah model regresi mempunyai korelasi antar variabel bebas. Berikut adalah hasil dari uji multikolinieritas. 
Tabel 4

Hasil Uji Multikolonieritas

\begin{tabular}{|c|c|c|c|c|c|c|c|c|}
\hline \multicolumn{9}{|c|}{ Coefficients $^{\mathrm{a}}$} \\
\hline \multirow[t]{2}{*}{ Model } & & \multicolumn{2}{|c|}{$\begin{array}{l}\text { Unstandardized } \\
\text { Coefficients }\end{array}$} & \multirow{2}{*}{$\begin{array}{c}\begin{array}{c}\text { Standardized } \\
\text { Coefficients }\end{array} \\
\text { Beta }\end{array}$} & \multirow[t]{2}{*}{$\mathrm{T}$} & \multirow[t]{2}{*}{ Sig. } & \multicolumn{2}{|c|}{$\begin{array}{c}\text { Collinearity } \\
\text { Statistics }\end{array}$} \\
\hline & & $\mathrm{B}$ & $\begin{array}{c}\text { Std. } \\
\text { Error }\end{array}$ & & & & Tolerance & VIF \\
\hline \multirow{4}{*}{1} & (Constant) & -2.269 & 0.555 & & -4.090 & 0.000 & & \\
\hline & Struktur & 0.021 & 0.006 & 0.131 & 3.251 & 0.002 & 0.681 & 1.469 \\
\hline & Modal & & & & & & & \\
\hline & Profitabilitas & 0.257 & 0.012 & 0.894 & 22.240 & 0.000 & 0.681 & 1.469 \\
\hline
\end{tabular}

a.Dependent Variable: Nilai Perusahaan

Sumber: Data diolah (2020)

Hasil dari tabel di atas diperoleh nilai VIF struktur modal sebesar 1,469 dan nilai VIF profitabilitas sebesar 1,469, dan nilai tolerance struktur modal sebesar 0,681 dan nilai tolerance profitabilitas sebesar 0,681. Dari hasil tersebut dengan menggunakan nilai tolerance maka semua variabel $>0,10$ dan nilai VIF $<10$, oleh karena itu dapat diartikan bahwa data bebas dari multikolinieritas. Uji Heteroskedastisitas, uji heteroskedastisitas bertujuan untuk menguji apakah dalam suatu model regersi terdapat ketidaksamaan variance dari residual satu pengamatan ke pengamatan lain. Berikut adalah hasil dari uji heterkedastisitas:

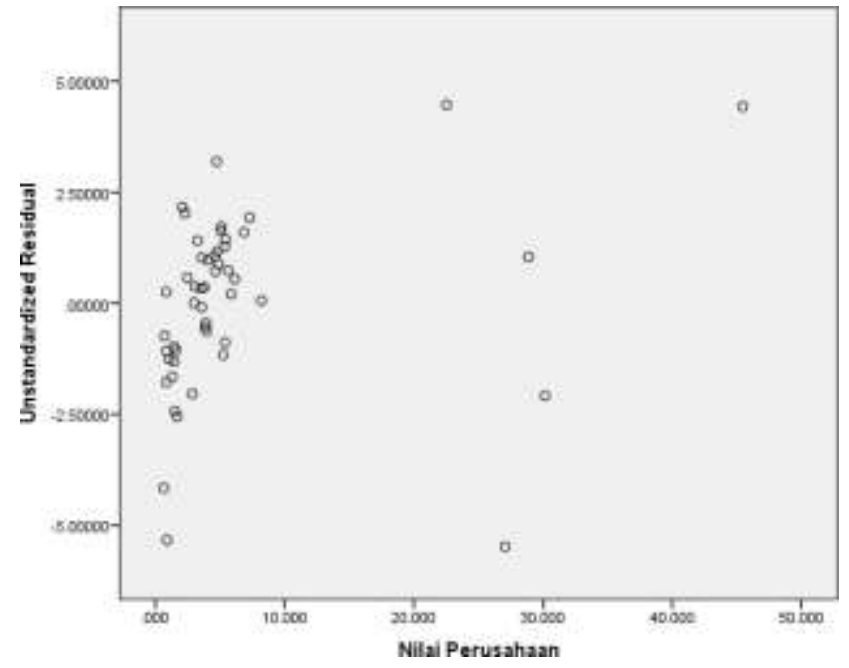

Gambar 1

Hasil Uji Heteroskedastisitas

Hasil uji heteroskedastisitas diatas dapat dilihat dimana titik-titik plot menyebar dan tidak memiliki pola yang jelas. Maka dapat disimpulkan bahwa model regresi dalam penelitian ini bebas dari gejala heteroskedastisitas. Uji Autokolerasi, uji autorelasi bertujuan untuk menguji apakah dalam suatu model regresi linier ada kolerasi antara kesalahan pada periode $t$ dengan periode $\mathrm{t}$ (sebelumnya). Berikut adalah hasil dari uji autokolerasi 


\section{Tabel 5}

\section{Hasil Uji Autokolerasi}

\begin{tabular}{lccccc}
\hline Model & $\mathrm{R}$ & $\mathrm{R}$ Square & $\begin{array}{c}\text { Model Summary } \\
\text { Adjusted R } \\
\text { Square }\end{array}$ & $\begin{array}{c}\text { Std. Error of } \\
\text { the Estimate }\end{array}$ & Durbin-Waston \\
\hline 1 & $0.974^{\mathrm{a}}$ & 0.948 & 0.946 & 2.050 & 1.276 \\
\hline
\end{tabular}

a.Predictors: (Constant), Profitabilitas, Struktur Modal

b.Depedent Variable Nilai Perusahaan

Sumber: Data diolah (2020)

Hasil uji autokolerasi diatas menunjukkan bahwa nilai Durbin-Watson sebesar 1,276 sehingga nilai DW di antara -2 dan +2 , itu berarti menunjukkan bahwa tidak terjadi autokorelasi pada variabel dalam penelitian ini. Analisis Regresi Linier Berganda

Tabel 6

Analisis Regresi Linier Berganda

\begin{tabular}{|c|c|c|c|c|c|c|c|c|}
\hline \multicolumn{9}{|c|}{ Coefficients $^{\mathrm{a}}$} \\
\hline \multirow[t]{2}{*}{ Model } & & \multicolumn{2}{|c|}{$\begin{array}{l}\text { Unstandardized } \\
\text { Coefficients }\end{array}$} & \multirow{2}{*}{$\begin{array}{c}\begin{array}{c}\text { Standardized } \\
\text { Coefficients }\end{array} \\
\text { Beta }\end{array}$} & \multirow[t]{2}{*}{$\mathrm{T}$} & \multirow[t]{2}{*}{ Sig. } & \multicolumn{2}{|c|}{$\begin{array}{c}\text { Collinearity } \\
\text { Statistics }\end{array}$} \\
\hline & & $\mathrm{B}$ & $\begin{array}{c}\text { Std. } \\
\text { Error }\end{array}$ & & & & Tolerance & VIF \\
\hline \multirow{4}{*}{1} & (Constant) & -2.269 & 0.555 & & -4.090 & 0.000 & & \\
\hline & Struktur & 0.021 & 0.006 & 0.131 & 3.251 & 0.002 & 0.681 & 1.469 \\
\hline & Modal & & & & & & & \\
\hline & Profitabilitas & 0.257 & 0.012 & 0.894 & 22.240 & 0.000 & 0.681 & 1.469 \\
\hline
\end{tabular}

a.Dependent Variable: Nilai Perusahaan

Sumber: data diolah, 2020

Berdasarkan hasil pengujian diatas dapat diperoleh persamaan regresi yaitu PBV $(\mathbf{Y})=\mathbf{- 2 , 2 6 9}$ + 0,021 DER + 0,257 ROE. Dari model regresi tersebut dapat diketahui nilai konstanta sebesar -2,269 artinya jika semua variabel bebas memiliki nilai 0 (nol) maka nilai variabel terikat sebesar -2,269. Kemudian nilai konstanta dari struktur modal (DER) sebesar 0,021 artinya jika struktur modal meningkat maka akan mengakibatkan nilai perusahaan pun meningkat sebesar 0,021. Sedangkan nilai konstanta dari profitabilitas (ROE) sebesar 0,257, artinya jika profitabilitas meningkat maka nilai perusahaan pun ikut meningkat sebesar 0,257. Uji Hipotesis, Uji Parsial (Uji-t). 
Tabel 7

\section{Hasil Uji Parsial (Uji-t)}

\begin{tabular}{|c|c|c|c|c|c|c|c|c|}
\hline \multicolumn{9}{|c|}{ Coefficients $^{\mathrm{a}}$} \\
\hline \multirow[t]{2}{*}{ Model } & & \multicolumn{2}{|c|}{$\begin{array}{l}\text { Unstandardized } \\
\text { Coefficients }\end{array}$} & \multirow{2}{*}{$\begin{array}{l}\text { Standardized } \\
\text { Coefficients } \\
\text { Beta }\end{array}$} & \multirow[t]{2}{*}{$\mathrm{T}$} & \multirow[t]{2}{*}{ Sig. } & \multicolumn{2}{|c|}{$\begin{array}{c}\text { Collinearity } \\
\text { Statistics }\end{array}$} \\
\hline & & $\mathrm{B}$ & $\begin{array}{c}\text { Std. } \\
\text { Error }\end{array}$ & & & & Tolerance & VIF \\
\hline \multirow{4}{*}{1} & (Constant) & -2.269 & 0.555 & & -4.090 & 0.000 & & \\
\hline & Struktur & 0.021 & 0.006 & 0.131 & 3.251 & 0.002 & 0.681 & 1.469 \\
\hline & Modal & & & & & & & \\
\hline & Profitabilitas & 0.257 & 0.012 & 0.894 & 22.240 & 0.000 & 0.681 & 1.469 \\
\hline
\end{tabular}

a.Dependent Variable: Nilai Perusahaan

Sumber: Data diolah (2020)

Pengaruh Struktur Modal terhadap Nilai Perusahaan

Berdasarkan hasil dari pengujian diatas diperoleh nilai $t_{\text {hitung }}$ sebesar 3,251. Dibandingkan dengan nilai $t_{\text {tabel }}$ sebesar 2,01063, maka nilai $t_{\text {hitung }} 3,251>$ dari nilai $t_{\text {tabel }} 2,01063$ dengan nilai signifikan $0,002<0,05$. Sehingga dapat disimpulkan bahwa $\mathrm{H}_{0}$ ditolak dan $\mathrm{H}_{1}$ diterima. Dengan demikian secara parsial struktur modal berpengaruh secara signifikan terhadap nilai perusahaan. Hasil penelitian ini sesuai dengan teori MM yang menyatakan apabila terjadi peningkatan nilai perusahaan akan disebabkan oleh penambahan utang selama struktur modal berada di bawah titik optimalnya, hal tersebut dijelaskan oleh Trade-off Theory dimana manfaat dari peningkatan utang masih lebih besar dari pengorbanan yang dikeluarkan sehingga secara langsung manfaat penggunaan utang tersebut meningkatkan nilai perusahaan. Peningkatan nilai perusahaan karena peningkatan jumlah utang yang disebabkan oleh manajemen perusahaan yang menggunakan utang untuk ekspansi usaha dari perusahaan. Hasil penelitian ini sejalan dengan penelitian yang dilakukan oleh Rita dan Irham (2018); Haven \& Fitty (2016); yang menunjukan bahwa adanya pengaruh positif dan signifikan anatara struktur modal dengan nilai perusahaan.

Pengaruh Profitabilitas terhadap Nilai Perusahaan

Berdasarkan hasil dari pengujian didapat nilai thitung sebesar 22,240. Dibandikan dengan nilai $t_{\text {tabel }}$ sebesar 2,01063, maka nilai $t_{\text {hitung }} 22,240>$ dari nilai $t_{\text {tabel }} 2,01063$. Dengan nilai signifikan $0,000<0,05$. Dapat disimpulakan bahwa $\mathrm{H}_{0}$ ditolak dan $\mathrm{H}_{2}$ diterima. Sehingga secara parsial profitabilitas berpengaruh secara signifikan terhadap nilai perusahaan. Hasil penelitian ini sesuai dengan teori Signal dimana dijelaskan bahwa investor akan meningkatkan permintaan saham apabila profitabilitas perusahaan meningkat, dan disisi lain pun dapat meningkatkan nilai perusahaan. Investor akan tertarik jika nilai ROE tinggi karena ROE merupakan rasio yang langsung menghitung pengembalian terhadap ekuitas yang ditanamkan oleh investor. Hasil penelitian ini sejalan dengan penelitian yang dilakukan oleh Mikhy \& Vivi (2016); Ayu dan Ari (2013); Syarinah (2017); Rudangga (2016); Rina, dkk (2019); Mamay dan Naufal (2019) yang menunjukan bahwa terdapat pengaruh positif antara profitabilitas dengan Nilai Perusahaan. 
Uji Simultan (Uji-F)

\section{Tabel 8}

Hasil Uji Simultan (Uji-F)

\begin{tabular}{rlrrrrl}
\hline \multicolumn{7}{c}{ ANOVA $^{\mathbf{a}}$} \\
\hline \multicolumn{1}{c}{ Model } & & Sum of Squares & \multicolumn{1}{c}{ df } & Mean Square & F & \multicolumn{1}{l}{ Sig. } \\
\hline \multirow{2}{*}{1} & Regression & 3624.869 & 2 & 1812.435 & 431.115 & $0.000^{\mathrm{b}}$ \\
& Residual & 197.591 & 47 & 4.204 & & \\
& Total & 3822.460 & 49 & & & \\
\hline
\end{tabular}

a.Dependent Variabel: Nilai Perusahaan

b.Predictor: (Constant), Profitabilitas, Struktur Modal

Sumber: Data diolah (2020)

Berdasarkan hasil diatas diperoleh nilai $F_{\text {hitung }}$ sebesar 431,115. Sehingga diperoleh nilai $F_{\text {hitung }}$ $>\mathrm{F}_{\text {tabel }}$ atau 431,115 > 3,190, dengan nilai signifikan $0,000<0,05$ artinya $\mathrm{H}_{0}$ ditolak dan $\mathrm{H}_{3}$ diterima. Dengan demikian dapat disimpulkan bahwa struktur modal dan profitabilitas berpengaruh secara signifikan terhadap nilai perusahaan.

Hasil penelitian ini sejalan dengan penelitian yang dilakukan oleh Rina, dkk (2019) dan Mamay dan Naufal (2019) yang menunjukan bahwa struktur modal dan profitabilitas berpengaruh terhadap nilai perusahaan.

Uji Koefisien Determinasi

Tabel 9

Hasil Uji Koefisien Determinasi

\begin{tabular}{|c|c|c|c|c|c|}
\hline \multicolumn{6}{|c|}{ Model Summary $^{b}$} \\
\hline Model & $\mathrm{R}$ & R Square & $\begin{array}{c}\text { Adjusted R } \\
\text { Square }\end{array}$ & $\begin{array}{l}\text { Std. Error of } \\
\text { the Estimate }\end{array}$ & Durbin-Waston \\
\hline 1 & $0.974^{\mathrm{a}}$ & 0.948 & 0.946 & 2.050 & 1.276 \\
\hline
\end{tabular}

Sumber: Data diolah (2020)

Hasil pengujian diatas dapat dilihat bahwa hasil dari koefesien determinasi atau $\mathrm{R}^{2}$ sebesar 0,948 atau sebesar $94,8 \%$. Hal ini dapat menunjukan bahwa variabel yang diteliti yaitu struktur modal yang diukur oleh debt to equity ratio dan profitabilitas yang diukur return on equity ratio berpengaruh sebesar $94,8 \%$ terhadap nilai perusahaan yang diukur dengan price to book value. Sedangkan sisanya 5,2\% dipengaruhi oleh variabel yang peneliti tidak teliti dalam penelitian ini.

\section{KESIMPULAN}

Berdasarkan hasil penelitian dapat diperoleh kesimpulan bahwa $\mathrm{H}_{1}$ diterima dan $\mathrm{H}_{0}$ ditolak sehingga dapat diartikan bahwa struktur modal berpengaruh positif secara signifikan terhadap nilai perusahaan pada perusahan sub sektor makanan dan minuman yang terdaftar di Bursa Efek Indonesia Periode 2014-2018, $\mathrm{H}_{2}$ diterima dan $\mathrm{H}_{0}$ ditolak yang dapat diartikan bahwa profitabilitas berpengaruh positif secara signifikan terhadap nilai perusahaan pada perusahan sub sektor makanan dan minuman yang terdaftar di Bursa Efek Indonesia Periode 2014-2018, dan $\mathrm{H}_{3}$ diterima $\mathrm{H}_{0}$ diolak yang dapat diartikan bahwa struktur modal dan profitabilitas secara bersama- sama berpengaruh positif secara signifikan terhadap nilai perusahaan pada 
perusahaan sub sektor makanan dan minuman yang terdaftar di Bursa Efek Indonesia periode 2014-2018.

\section{SARAN DAN KETERBATASAN}

Penelitian ini memiliki keterbatasan dalam penggunaan variabel yang tidak dimasukan dalam penelitian dikarenakan oleh keterbatasan sumber dan waktu penelitian. Oleh karena itu untuk peneliti selanjutnya diharapkan dapat menambah variabel penelitian selain dari variabel yang digunakan dalam penelitian ini misalnya dengan menambahkan variable kebijakan deviden, ukuran perusahaan, dan likuiditas.

\section{DAFTAR PUSTAKA}

Hartanti, R, Yulandani, F, \& Riandi, MR. (2019). The Efect of Profitability, Capital Structure, And Implementation of Corporate Governance on Company Value. Vol. 6. No. ISSN: 2339-0832.

Ismail. (2017). Akuntansi Bank Teori dan Praktik dalam Rupiah, Edisi Revisi. Jakarta: Kencana. ISBN: 978-979-1486-85-9

Komarudin, M, \& Affendi, N. (2019). Firm Value, Capital Structure, Profitability, Firm Characteristic and Disposable Income as Monderator: an Empirical Investigation of Retail Firms in Indonesian. Vol.7. pp 79-85. ISSN: 2614-6983

Kusumawati, R \& Rosady, I. (2018). Pengaruh Struktur Modal dan Profitabilitas terhadap Nilai Perusahaan dengan Kepemilikan Manajerial sebagai Variabel Moderasi. Jurnal Manajemen Bisnis. Vol.9 No.2. ISSN: 2086-8200.

Manoppo, H, \& Arie FV. (2016). Pengaruh Struktur Modal, Ukuran Perusahaan, dan Profitabilitas terhadap Nilai Perusahaan Otomotif yang Terdaftar di Bursa Efek Indonesia Periode 2011-2014. Jurnal EMBA. Vol.4 (2) Hal: 485-497. ISSN:2303-1174.

Novari, M, \& Lestari PV. (2016). Pengaruh Ukuran Perusahaan, Laverage, dan Profitabilitas terhadap Nilai Perusahaan Pada Sektor Properti dan Real Estate. E-Jurnal Manajemen Unud. Vol.5 No.9. ISSN: 2302-8912.

Purwandoko. (2017). The Influence of Firms Size, Growth, and Profitability on Firm Value with Capital Structure as The Mediator: A Study on The Agricurtural Firms Listed In The Indonesian Stock Exchange. Vol. 9 No. 8 ISSN: 1916-9728.

Ratih, IDA \& Ayu IGED. (2016). Kepemilikan Manajerial dan Profitabilitas pada Nilai Perusahaan dengan Pengungkapan TanggungJawab Sosial sebagai Variabel Pemoderasi. E-Jurnal Akuntansi Universitas Undaya. Vol.4 No.6. ISSN: 2302-8556

Rochaety, E, Tresna, R, \& Latief, AM. (2019). Metodologi Penelitian Bisnis Dengan Aplikasi SPSS, Edisi 2. Jakarta: Mitra Wacana Media. ISBN: 978-602-318-392-0.

Rudangga, ING, \& Sudiarta, GM. (2016). Pengaruh Ukuran Perusahaan, Laverage, dan Profitabilitas terhadap Nilai Perusahaan. E-Jurnal Manajemen Unud. Vol.5 No.7. ISSN: 2302-8912.

Sadewo,IB, Suparlinah, I \& Widianingsing, R. (2016). Pengaruh Ukuran Perusahaan dan Keputusan Pendanaan Terhadap Nilai Perusahaan dengan Profitabilitas sebagai Variabel Mediasi (Studi Empiris Perusahaan Manufaktur di Bursa Efek Indonesia pada Tahun 2011-2016). ISSN: 2460-0784. 
Sagoro, EM. (2015). Akuntansi Tanpa Stres, Yogyakarta: AB Publiser. ISBN: 978-602-714446-0

Sianpar, S. (2017). Pengaruh Struktur Modal dan Profitabilitas Terhadap Nilai Perusahaan pada Sektor Makanan dan Minuman yang terdaftar di Bursa Efek Indonesia. Vol.4 No 1. ISSN: 2355-6919.

Sugiyono. (2014). Metode Penelitian Manajeme. Bandung: Alfabeta. ISBN: 978-602-7825-666

(2016). Metode Penelitian Kuantitaf,kualitatif, dan R\&D. Bandung: Alfabeta. ISBN: 979-8433-64-0

Suharyadi \& Purwanto. (2016). Statistika Untuk Ekonomi dan keuangan Modern Edisi 3, Buku 2. Jakarta: Salemba Empat. ISBN: 978-979-061-446-8.

Sulastri, Yuliani, Hanafi, A, \& Dewi, A. (2018). The Efect of Stock Ownership Structure, Capital Structure, And Profitability to Firm Value In Manufacturing Company Sector In Indonesian Stock Exchange. Vol.7 ISSUE 11. ISSN: 2277-8616

Tas, O \& Ede, S. (2018). The Efect of Capital Structure On The Value of Firm. A Study of Turkey Non-Metal Mineral Products Index. Vol.8 No.1-2 p 34-37. ISSN: 2459-0762.

Utari, D, Purwanti, A, \& Prawironegoro, D. (2016). Akuntansi Manajemen Edisi 4. Jakarta: Mitra Wacana Media. ISBN: 978-602-318-177-3.

www.cnnindonesia.co.id (diakses pada 15 Januari 2020)

www.idx.co.id (diakses pada 15 Januari 2020)

www.indonesiainvesments.com (diakses pada 15 Januari 2020)

www.kemenperin.go.id (diakses pada 15 Januari 2020)

www.sahamok.com (diakses pada 15 Januari 2020) 